journalhomepage:http://chimie-biologie.ubm.ro/carpathian_journal/index.html

\title{
SWEET MARJORAM (ORIGANUM MAJORANA L.) AS A MAGICAL BIO- PROTECTIVE AGENT AGAINST FOOD SPOILAGE: A REVIEW
}

\author{
Khushbo Bhardwaj ${ }^{1}$ and Widhi Dubey ${ }^{1}$ \\ ${ }^{1}$ Faculty of Science, JECRC University, Sitapura, Vidhani, Jaipur, Rajasthan 303905 \\ 凶idhidubey10@gmail.com
}

\begin{abstract}
https://doi.org/10.34302/crpifst/2020.12.1.1
Article history:

Received:

4 October 2019

Accepted:

4 February 2020

Keywords:

Origanummajorana L.,

Antimicrobial,

Preservative,
\end{abstract}

Food industry

\section{Introduction}

Commercialization and globalization of food industry is facing main task of increasing importance of food safety and quality. Food products specially packaged food is vulnerable to contamination by various environmental and food borne microorganisms which are responsible for producing unwanted and unpleasant changes in food taste and odour. Some of the microorganisms produce harmful toxins spreading illness in consumers. A study shows that approximately $20 \%$ of eatable vegetables and fruits collected for population consumption are vanished due to storage spoilage caused by these micro-attackers (Barth et al, 2009). It is proved that amount of high water present in these food items provide a better home for microbes to feed and grow on them (Jay, 2003). Abundant amount of minerals, vitamins and fibres can be obtained from fresh fruits and vegetables at a lower cost (Nagy and Shaw, 1985). Due to the attack of spoilage microbes like bacteria and fungi the adequate supply of fresh items is hampered with the changing weather in surrounding (Ihekoronye and Ngoddy, 1985). For avoidance of this weather dependent microbial spoilage farmers opt for sun drying of vegetables and fruits which leads to loss of some important vitamins and minerals in them (Gallali et al., 2000). Similarly illness leading to death in some cases, caused by food borne pathogens is one of the main issues in undeveloped countries. The microorganism mainly responsible for deterioration and spoilage of food all over the world is fungi (Ihekoronye and Ngoddy, 1985; Gallali et al., 2000).

Increased incidences of foodborne toxicity and illness simultaneously accounting for financial losses to farmers, suppliers and consumers put strain on production of safe and good quality food in fresh as well as packaged form. (Beraha et al., 2009; Jay, 2003). It is therefore needed to use strong preservative methods to maintain the quality and availability of nutrients (vitamins and minerals) in fresh fruits and vegetables. The international standards released by FAO, also directs to use safe preservatives to maintain food quality (processed or raw) that it should be nourishing and contaminants free (Jay, 2003; Ihekoronye and Ngoddy, 1985). 
Therefore in past years use of synthetic chemicals was increased as a source to protect microbial activity thus preventing microbial enzymes from spoiling fresh and packaged food. It has been advocated that some chemical based preservatives are harmful for consumers as they are able to convert some ingested items into toxic substances and carcinogens as reported in some cases (Nagy and Shaw, 1985). Hence, in the recent decade producers and stakeholders are constantly facing significant pressure to reduce or stop use of chemical based preservatives. As a result of this pressure and concern, antimicrobials from natural sources have received attention from manufacturers for their potent use as antimicrobial additive for food items.

\section{Plants as natural preservatives}

Plant products have been proved as important natural remedy for treatment of many health and beauty issues of human being. Many plant based products are in market and attracted a huge population due to their safer and strong desirable properties. Among these marketable products, green antimicrobials are in recent trends for use as antimicrobial and antioxidative agents for preservation of food items. Though their traditional use has already occupied our kitchens as taste enhancers or texture improvers, they always possessed antimicrobial properties (Beraha et al., 2009; Jay, 2003). Some of the plant products have been used in various cosmetic productions due to their pleasant aroma. Recently, use of essential oils has increased for their curative effects in aromatherapy (Nagy and Shaw, 1985). Essential oils form various plant parts are largely being utilized in pharmaceutical and other related drug developmental programmes.

Extracts and essential oils of many plants have been known to exhibit antagonist effect against a variety of food spoilage microbes (Amit et al., 2017). On the other hand these herbs have been proved to have substances that are capable of enhancing the taste and odour of regular food items. Some herbs possessing bactericidal or bacteriostatic properties are used as preservative in packaged meat (Dyankova et al., 2009). Since decades, chemical antioxidants are extensively used to protect food quality mainly by oxidatioon of lipid components of food items. Synthetic antioxidants such as butylated hydroxylanisole (BHA) and butylated hydroxyltoluene (BHT) are among mainly used inhibitors of lipid peroxidation which is capable of maintaining stability of lipids in food-stuffs (Moure et al., 2001; Tohma et al., 2016). However, as consumers have become aware of their carcinogenic nature, the use of synthetic antioxidants is now restricted by law (Stone et al., 2003; Bae et al., 2016). In this context, natural products have again gained interest of researchers and industrialists as they seem to be healthier as and safer (Topal et al., 2015a; Oztaskin, et al., 2015; Polat et al., 2015). In the recent years, spices and herbs have been used as antioxidants in processed foods as a promising alternative of synthetic antioxidants (Topal et al., 2015b).Various studies have demonstrated that essential oils obtained from different plant parts of Origanum spp. express a range of different biological activities, such as cytotoxic, antifungal, antioxidant, anti-inflammatory, antibacterial and insecticidal (Dyankova et al., 2009).

\subsection{Origanum majorana as food spoilage protective agent:}

The sweet marjoram (Origanum majorana L.) is a member of notably important family of economically and industrially useful plants in all forms i.e. fresh and dried. Since decades, it has been widely used as a household herb for treatment of various disorders and health issues (Table 1). These properties are attributed due to presence of many compounds such as terpenoids, phenols, esters etc. in different derivative forms.

These compounds are synthesized and stored in various plant parts such as leaves, flowers, stem etc. (Table 2). Its leaves are rich in aroma; flowers are used with other spices as condiment to enhance flavour and odour of many food items. It is commonly known as sweet marjoram and murua because of its 
pleasant smell. Essential oil extracted from whole plant is also being used as flavouring agent in various commercially sold food stuff and beverage.

Table 1. Medicinal use of different parts of $O$. majorana

\begin{tabular}{|l|l|l|}
\hline S.No. & Plant part used & Medicinal property \\
\hline 1. & Leaves & $\begin{array}{l}\text { Antimicrobial, antiseptic, carminative, antitussive and } \\
\text { used for gastrointestinal disorder, unilateral facial } \\
\text { paralysis, headache, epilepsy, cataract, weakness of } \\
\text { sight, ear pain, dyspnea, cardiac pain, } \\
\text { spondylolisthesis, groin pain, back pain, fatigue, } \\
\text { freckle, migraine, bronchial coughs. }\end{array}$ \\
\hline 2. & Essential oil & $\begin{array}{l}\text { Flatulence, nervousness, diuretic, sedative toothache, } \\
\text { muscular pain, asthma. }\end{array}$ \\
\hline
\end{tabular}

Table 2. Main compounds attributing properties of $O$. majorana

\begin{tabular}{|l|l|l|}
\hline S.No. & Class of compounds & Main compounds present \\
\hline 1. & Monoterpenoids & $\begin{array}{l}\text { a-pinene, beta-pinene, sabinene, myrcene, a- } \\
\text { terpinene, y-terpinene, paracymene, } \\
\text { terpinolene, a-phellandrene, beta- } \\
\text { phellandrene }\end{array}$ \\
\hline 2. & Sesquiterpenoids & $\begin{array}{l}\text { beta-caryophyllene, a-humulene } \\
\text { linalool, terpine-1-ol-4, terpine-1-ol-3, a- } \\
\text { terpineol, cis-thuyanol-4, trans- } \\
\text { thuyanol-4 }\end{array}$ \\
\hline 3. & Monoterpenols & $\begin{array}{l}\text { linalyl acetate, terpenyl acetate, geranyl } \\
\text { acetate }\end{array}$ \\
\hline 4. & Terpenic esters & $\begin{array}{l}\text { trans-ethanol } \\
\text { incyclic monoterpene alcohol, cis-sabinene } \\
\text { hydrate, a-terpinene, 4-terpineol, a- } \\
\text { terpineol, terpinenyl-4-acetate, and 1, 8- } \\
\text { cineol }\end{array}$ \\
\hline 5. & Phenol-methyl-ethers & Aroma components \\
\hline
\end{tabular}

3. Food preservative quality of sweet marjoram has been accessed on following points:

\subsection{As Antioxidant}

There have been several lab reports for its antioxidant activity against commonly found food spoilage. It is well known that the main cause of food deterioration is oxidative rancidity due to which finally rejected by consumers as spoiled food has bad odour, taste and texture (Embuscado, 2015b). Therefore, Some herbs and spices, such as oregano, thyme, ginger, black pepper, clove, marjoram, basil, peppermint, balm, fennel, parsley, cinnamon, cumin, nutmeg, garlic and coriander are added to lipid containing foods as they possess antioxidative properties which however stabilize lipids in food products by reducing their oxidation (Yanishlieva et al., 2006). Sweet marjoram is reported to be rich in compounds like beta-carotene, beta-sitosterol, caffeic acid, carvacrol, eugenol, hydroquinone, linalylacetate,rosmarinic acid, terpinen-4-ol, betacarotene, caffeic acid, tannin, phenol, transanethole, ursolic acid and oleanolic acid which makes it a good scavenger of free radicals present in food items (Embuscado, 2015a and b). 
This antioxidative property has attracted many researchers to analyse its activity in in-vitro and in-vivo. Amarowicz (2009) extracted phenolic compounds from thyme (Thymus vulgaris L.), oregano (Origanum vulgare L.) and marjoram (Origanum majorana L.) with solvent ethanol and observed that antioxidant activity of extracts of marjoram was highest.

It is also observed that marjoram essential oil added with oils of rosemary has been proved to control and reduce lipid oxidation in beef patties (Mohamed and Mansour, 2012). Fried mullet and fish fillets coated with mixture of thyme $(2.5,5 \%)$ and marjoram $(2.5,5 \%)$ showed strong effects against species of family Enterobacteriaceae (Yasin and Abou talab, 2007). Lucera and colleagues (2012) also concluded this study in their review analysing preservative properties of some spices specially marjoram and thyme. Antioxidant property of thyme, sage and marjoram extract was examined in an experiment by using DPPH assay and results revealed that thyme, marjoram and sage presented stronger antioxidant activity in comparison to BHT and BHA (Hussein et al., 2012). Saeed and colleagues reviewed work of (Goni et al., 2009) on marojarm and oregano and observed that marjoram along with oregano essential oil is very effective antagonist for gram positive and negative bacteria. Activity of ethanol and hexane extracts of some herbs and spices including sweet marjoram have been assayed and reported upto $50 \%$ reduction in growth of food spoilage (Witkowskaet al., 2013).

Gutierrez et al., (2008) tested efficacy of essential oils in different combinations and found additive effects against $E$. coli and $P$. aeruginosa, when oregano was used in combination with thyme, marjoram or basil. Nessrien (2007) investigated deleterious effect of marjoram and thyme on the microbes spoiling the quality of semi fried mullet fish fillets during cold storage. Marjoram is well known to have antioxidant activity as well as therapeutic properties as assayed in various studies (Vagi et al., 2005; Tsai et al., 2007; Lopez et al., 2007; Yazdanparast and Shahriyary 2008; Al-
Howiriny et al., 2009; Abdel-Massih et al.,2010; Viuda-Martos et al., 2010; Mossa and Nawwar 2011; Hossain et al., 2012). Anti-oxidant potential of this plant has been tested by various researchers (Ayari and Landoulsi, 2013; Erenler et al., 2016; Baatour et al., 2011) and they strongly recommend industrial application of this plant as food preservative.

\subsection{As Antimicrobial Agent}

In recent years its antimicrobial property has also attracted researchers and commercialist to use it as anti-spoilage agent in packaged food stuff. From Egypt it has been reported that a moderate activity was observed for all tested concentrations against common food borne bacteria viz. Bacillus cereus (Selim et al., 2013). In a different study it was found that it was highly active against Bacillus subtilis, followed by Staphylococcus aureus (Joshi et al., 2009). Fungistatic and fungicidal effect of essential oil of this plant has been reported on Verticillium dahliae and Penicillium aurantiogriseum; wellknown disastrous fungi. These fungi are notoriously known for their post-harvest spoilage and deleterious effect on storage food (Rus et al., 2015). The antibacterial effect of essential oils (EOs) Origanum majorana, and some other plants have been investigated on two food borne bacteria viz. Bacillus cereus and Escherichia coli and the most effective antibacterial activity was obtained with marjoram and clary sage oil, alone and in combination (Tserennadmid et al., 2010). The antibacterial potential of marjoram along with some other herbs was screened against food borne pathogens including Staphylococcus aureus, Listeria monocytogenes, Escherichia coli, Salmonella Typhimurium and Bacillus cereus and observed differential susceptibility of pathogens towards the extracts used.

It has also been reported in the same study that essential oils of marjoram contains alcoholic terpenoids which gives it potent antagonistic nature against food borne microbes (Shenawy et al., 2015). Antagonist effect of Origanum majorana L. (marjoram) essential oil has been reported against cultures of Salmonella 
spp., Shigella, Proteus, E. coli, Citrobacter and Pseudomonas species isolated from poultry meat. This study claims that the essential oil of marjoram was more effective in comparison to conventionally used antibiotics such as amoxiclav (amoxicillin / clavulanic acid) against which these strains showed high resistance. Even Salmonella strain was more susceptible in comparison to other tested strains to antimicrobial action of marjoram essential oil (Marquesa et al., 2015). It was also recommended that essential oil and other extracts of marjoram could be used as a potent bio-protective agent for preservation of refrigerated meat. Thus, marjoram essential oil can play an important role as antimicrobial agent in refrigerated minced meat and potentially it might be used as a natural preservative ingredient for longer periods without the need to use hazardous preservatives in food industry (Omara et al., 2014). Extracts of plants specially spices have been traditionally used as an ingredient of food items but essential oil of spices has also been proved to work as preservative due to their antimicrobial activity against various food borne pathogens (Marquesa et al., 2015). The most commonly found and most notorious food borne pathogen responsible for usual intoxication and consequent illness is Staphylococcus aureus. Extracts of marjoram have been found to possess strong antagonistic effect against this bacterium also (Gottardi et al., 2016).

In a different study it was observed that different extracts of Origanum majorana L. (from various solvents) showed notably strong deleterious effect on Staphylococcus aureus, protozoa Pentatrichomonas hominis and six Candida sp. strains used (Srinivasan, 2014). Soxhlet extract of n-hexane, aqueous-ethanol extract and ethanolic- ammonia extracts were assessed in in-vitro assay for their activity against twenty pathogenic strains. It was found that n-hexane extract exhibited the highest antagonist activity and was capable to inhibit growth of maximum number of Staphylococcus aureus strains tested. The other bacteria showed resistance to almost all extracts, but Acinetobacter baumannii indicated a little growth inhibition by aqueous-ethanol extract. The extracts were also vigorous against three out of six Candida sp. strains tested, likewise ethanolic-ammonia extract was notably capable to reduce viability of $P$. hoministrophozoites by $50 \%$ at $160 \mu \mathrm{g} / \mathrm{ml}$ concentration the remaining extracts were found considerably less active (Kozlowska et al., 2010).

It is also found that essential oil of marjoram plant and coriander has capability to stop Aspergillus flavus infestation in chickpea seeds upto $50 \%$ (Prakash et al., 2012). Origanum majorana is also found effective against food borne pathogens B.subtilis, E.coli (Leeja and Thopil, 2007), P.aeruginosa, S .aureus and A.niger (Srinivasan, 2014). Potential of many spices including sweet marjoram against food spoilage microbes has been assessed and the results showed that spices such as marjoram possess substantial antimicrobial activity against food spoilage bacteria like Bacillus subtilis and Pseudomonas fluorescens as well as against food borne pathogens like Staphylococcus aureus and Vibrio parahaemolyticus.

It is also evident that oils of this plant are deleterious for harmful fungi like Aspergillu sflavus and also reported that its essential oil shows activity against antibiotic resistant microorganisms also such as methicillin resistant Staphylococcus aureus (Liu et al., 2017). Marques et al., (2015) also reported the antimicrobial activities of the EOs of marjoram against $S$. aureus isolated from poultry meat. In an antimicrobial investigation it was observed that Candida albicans was significantly susceptible to the action of marjoram essential oil in comparison to commercial antifungal agent (Badee et al., 2013). 
Table 3. Microorganisms susceptible to contents of O.majorana extract

\begin{tabular}{|l|l|}
\hline Bacteria & Fungi \\
\hline Escherichia coli & Candida rugosa \\
Pseudomonas aeruginosa & Debaryomyces hansenii \\
Salmonella poona & Kluyveromyces marxianus \\
Helicobacter pylori & Rhodotorula glutinis \\
& Rhodotorula minuta \\
& Saccharomyces cerevisiae \\
& Trichosporon cutaneum \\
& Yarrowia lipolytica \\
& Zygosaccharomyces rouxii \\
\hline
\end{tabular}

Broth microdilution and agar diffusion methods were used to evaluate the antibacterial activity of Origanum majorana L. oil collected from Tunisia against 10 bacteria. The observation showed that this oil was highly vigorous against all of the tested strains. The most susceptible were Streptococcus group A, Salmonella enteritidis, Shigella dysenteria and Escherichia coli. Some of the bacteria were less susceptible to the tested concentrations of this oil; the least susceptible bacterium was Pseudomonas aeruginosa (Ben Ezzeddineet al., 2001).

In In vitro experiments it is showed that essential oil of $O$. majorana shows highly effective antimicrobial and antifungal activity against five bacteria and one yeast strain studied (Stefanakis et al., 2013).

An effective mixture was prepared which corresponded to $28 \%, 30 \%$ and $42 \% O$. compactum, $O$. majorana and $T$. serpyllum, respectively and tested against Bacillus subtilis and Staphylococcus aureus.

This mixture depicted inhibition of $E$. coli at $75 \%$ and $25 \%$ of $O$. compactum and $O$. Majorana essential oils respectively. This finding clearly advocates use of $O$. majorana in successful application as natural preservatives in foods (Ouedrhiri et al., 2016). Similarly Staphylococcus aureus and Enterococcus faecalis have been found to supressed at concentrations of 0.4 to $3.2 \mathrm{mg} \mathrm{ml}^{-1}$ of essential oil of this plant. However, leaves and stems have shown maximum antimicrobial effects. The studies on antimicrobial activity of Origanum majorana L. essential oil have showed that it possess an important antagonist activity against various bacterial strains (Ibrahim et al., 2017). Mith and colleagues (2014) tested essential oil of sweet marjoram enriched with Terpinene-4-ol (24.21), a-terpinene (8.44), sabinene (7.12) and observed its excellent antagonistic action against Gram-negative bacteria than Gram-positive bacteria and stated that these materials can served assignificant natural alternative to control bacterial growth in food products. Chouhan et al., (2017) explained in their comprehensive review on present status and future prospective of plant antimicrobials in food preservation and stated that the essential oil of marjoram can be successfully used to prevent growth of Clostridium perfringens strain (Radaelli et al., 2016).

Phenol compounds extracted and identified from sweet marjoram has attracted researchers in recent years because of its strong biological activities especially antimicrobial, antifungal and antioxidant. These properties make it a suitable replacement of conventionally used food preservatives in food industry (Baatour et al., 2011; Baatour et al., 2013). Carvacrol, terpinen-4-ol, andterpinen-4-ol and thymol are the majorly found compounds in sweet marjoram EO (Busatta et al., 2007). These compounds express high antimicrobial property in in-vitro as exposure of bacterial cells to compounds like results in increased membrane fluidity facilitating seepage of protons and potassium ions which finally lead to collapse of the membrane and ultimately cell death (Baatour et al., 2013; Freire et al., 2011). 
Conversely, Cox et al., (2000) also confirmed that terpinen is also among the major compounds of marjoram EO which can inhibit oxidative respiration, a lethal action causing cytoplasmic membrane damage. It is also observed in some studies that marjoram essential oils are rich in phenolic compounds which attributes its potential both antioxidant and antimicrobial (Leeja and Thoppil, 2007 ; Sagdic et al., 2010). In other studies also antimicrobial properties of sweet marjoram have been evaluated which makes it a suitable substitute of chemical based preservatives (Table 3).

\section{Conclusions}

In conclusion, it is shown in this review that this plant possess many biological activities such as antibacterial, antifungal and antioxidant, which make it a suitable replacement of commonly used chemical based food preservatives. It is clear from tis review that many researchers have strongly recommended use of essential oil of $O$. majorana as a natural preservative ingredient in food industry. All parts of this plant have been proven to possess antioxidant and antimicrobial compounds so these might present important supplementary sources for use in food industries. Though, investigations are required to perform on its toxicity and other pharmacological aspects before its prominent use in food industry.

\section{References}

Amit, S. A., Uddin , M.M., Rahman, R., Islam, S.M.R., Khan, M.S., (2017). A review on mechanisms and commercial aspects of food preservation and processing. Agricultural \& Food Security, 6(51), 1-22.

Amarowicz, A., Egarska, Z. Z., Rafałowski, R., Pegg, R.B., Karamac, M., Kosinska, A., (2009). Antioxidant activity and free radical-scavenging capacity of ethanolic extracts of thyme, oregano, and marjoram. Euopean Journal of Lipid Science and Technolology, 111, 1111-1117
Al-Howiriny, T., Alsheikh, A., Alqasoumi, S., Al-Yahya, M., ElTahir, K., Rafatullah, S., (2009). Protective effect of Origanum majorana L. 'Marjoram' on various models of gastric mucosal injury in rats. American Journal of Chinese Medicine, 37(3), 531545.

Abdel-Massih, R.M., Fares, R., Bazzi, S., ElChami, N., Baydoun, E., (2010). The apoptotic and anti proliferative activity of Origanum majorana extracts on human leukemic cell line. Leukemia Research, 34(8), 1052-1056.

Ayari, B., Landoulsi, A., (2013). Variability of phenolic contents in Origanum majorana L. Methanolic extract among plant organs and effect on antioxidant and antimicrobial activities. International Journal of Agronomy and Plant Production, 4, 28062815.

Barth, M., Hankinson, T.R., Zhuang, H., Breidt, F., (2009). Microbiological Spoilage of Fruits and Vegetables. In: Sperber, W.H., Doyle, M.P. (Ed.), Compendium of the Microbiological Spoilage of Foods and Beverages.(pp. 135-183),Newyork, Epublishing Inc.

Bae, J. H., Park, Y. J., Namiesnik, J., Gulcin, İ., Kim, T. C., Kim, H. C., Heo, B. G., Gorinstein, S., Ku, Y. G., (2016). Effects of Artificial Lighting on Bioactivity of Sweet Red Pepper (Capsicum annuum L.). International Journalof Food Science and Technology, 51(6), 1378-1385.

Baatour, O., Kaddour, R., Mahmoudi, H., Tarchoun, I., Bettaieb, I., Nasri, N., Mrah, S., Hamdaoui, G., Lachaal, M., Marzouk, B., (2011). Salt effects on Origanum majorana fatty acid and essential oil composition. Journal of the Science of Food and Agriculture, 91(14), 2613-2620.

Badee, A.Z.M., Moawad, R.K., ElNoketi, 1M.M., Gouda, M.M., (2013). Antioxidant and Antimicrobial Activities of Marjoram (Origanum majorana L.) Essential Oil. Journal of Applied Sciences Research, 9(2), 1193-1201. 
Ben Ezzeddine, N.B.H., Abdelkefi, M.M., Aissa, R.B., Chaabouni, M.M., (2001). Antibacterial screening of origanum majorana 1. oil from tunisia, Journal of Essential Oil Research, 13(4), 295-297.

Baatour, O., Mahmoudi, H., Tarchoun, I., Nasri, N., Trabelsi, N., Kaddour, R., Zaghdoudi, M., Riadh, G.H., Lachaal, M., Marzouk, B., (2013). Salt effect on phenolics and antioxidant activities of Tunisian and Canadian sweet marjoram (Origanum majorana L.) shoots. Journal of the Science of Food and Agariculture, 93(1), 134-141.

Busatta, C., Vidal, R.S., Popiolski, A.S., Mossi, A.J., Dariva, C., Rodrigues, M.R.A., Corazza, F.C., Corazza, M.L., Vladimir, O.J., Cansian, R.L., (2007). Application of Origanum majorana L. essential oil as an antimicrobial agent in sausage. Food Microbiolgy, 25(1), 207-211.

Cox, S.D., Mann, C.M., Markham, J.L., Bell, H.C., Gustafson, J.E., Warmington, J.R., (2000). The mode of antimicrobial action of the essential oil of Melaleuca alternifolia (tea tree oil). Journal of Applied Microbiology, 88(1), 170-175.

Chouhan, S., Sharma, K., Guleria, S., (2017). Antimicrobial activity of some essential oils present status and future perspectives. Medicines (Basals),4(3), 1-21.

Dyankova, S., Dyakova, A., Miteva, D., Garbacheva, M., (2009). Study on antibacterial activity of some spice extracts used in the meat industry. Agricultural science and Technology. 1, 43-47.

Embuscado, M. E., 2015b, Herbs and spices as antioxidants for food preservation. In $\mathrm{F}$. Shahidi (Ed.), Handbook of antioxidants for food preservation. pp. 251-283, New York, Woodhead Publishing.

Embuscado, M. E., (2015)a. Spices and herbs: Natural sources of antioxidants - a mini review. Journal of Functional Food, 18, 811-819.

Erenler, R., Sen, O., Aksit, H., Demirtas, I., Yaglioglu, A.S., Elmastasa, M., Telci, I., (2016). Isolation and identification of chemical constituents from Origanum majorana and investigation of antiproliferative and antioxidant activities. Journal of the Science of Food and Agriculture,96(3), 822-836.

Freire, J.M., Cardoso, M.G., Batista, L.R., Andrade, M.A., (2011). Essential oil of Origanum majorana L., Illicium verum Hook.f. and Cinnamomum zeylanicum Blume: chemical and antimicrobial characterization. RevistaBrasileira de PlantasMedicinais, 13(2), 209-214.

Gallali, Y. M., Abujnah, Y.S., Bannani, F.K., (2000). Preservation of fruits and vegetables using solar drier: a comparative study of natural and solar drying, III; chemical analysis and sensory evaluation data of the dried samples (grapes, figs, tomatoes and onions). Renewable energy, 19(1-2), 203212.

Goni, P., Lopez, P., Sanchez, C., Gomez-Lus, R., Becerril, R., Nenn, C., (2009). Antibacterial activity in the vapour phase of a combination of cinnamon and clove essential oils. Food chemistry, 116(4), 982989.

Gutierrez, J., Barry-Ryan, C., Bourke, P., (2008). The antimicrobial efficacy of plant essential oil combinations and interactions with food ingredients. International Journal of Food Microbiology.124(1), 91-97.

Gottardi, D., Bukvicki, D., Prasad, S., and Tyagi, A.K., (2016). Beneficial Effects of spices in food preservation and safety. Frontiers in Microbiology, 7, 1-20.

Hussein, M. Roby, H., Sarhan, M.A., Selim, K.A.H., Khalel, K.I., (2012). Evaluation of antioxidant activity, total phenols and phenolic compounds in thyme (Thymus vulgaris L.), sage (Salvia officinalis L.), and marjoram (Origanum majorana L.) extracts. Industrial Crops and Products, 43, 827-831. Hossain, M.B., Brunton, N.P., Patras, A., Tiwari, B., O'Donnell, CP., Martin-Diana, AB., Barry-Ryan, C., (2012). Optimization of ultrasound assisted extraction of antioxidant compounds from marjoram (Origanum majorana L.) using response 
surface methodology. Ultrasonics Sonochemistry, 19(3), 582-590.

Ihekoronye, A.I., Ngoddy, P.O., (1985). Food Microorganisms and Food Spoilage, In Integrated Food Science and Technology for the Tropics. (pp.106-107), London, Macmillan Publishers.

Ibrahim, F.A., Bellail, A.A., Hamad, A.M. and Idjeri, S.M., (2017). Antimicrobial activities and chemical composition of the essential oil of Origanum majorana 1. growing in Libya. International Journal of Pharmacy and Pharmaceutical Research, 8(3), 1-11.

Jay, J.M., (2003). Microbial Spoilage of Food, in Modern Food Microbiology, Chapman and Hall Inc. New York, 4th edn. 2003, pp. 187-195.

Joshi, B., Lekhak, S., Sharma, A., (2009). Antibacterial Property of Different Medicinal Plants: Ocimum sanctum, Cinnamomum zeylanicum, Xanthoxylum armatum and Origanum majorana. Kathmandu University Journal of Science, Engineering and Technology.5(1), 143- 150.

Kozłowska, M., Laudy, A.E., Starościak, B.J., Napiorkowski, A., Chomicz, L., Kazimierczuk, Z., (2010). Antimicrobial and antiprotozoal effect of sweet marjoram (Origanum majorana L.). Acta Scientiarum Polonorum Hortorum Cultus, 9(4), 133-141.

Lucera, A., Costa, C., Conte, A., Del Nobile, M.A.E., (2012). Food applications of natural antimicrobial compounds. Frontiers in microbiology, 3, 1-13.

Lopez, V., Akerreta, S., Casanova, E., GarcíaMina, J.M., Cavero, R.Y., Calvo, M.I., (2007). In vitro antioxidant and antirhizopus activities of Lamiaceae herbal extracts. Plant Foods for Human Nutrition, 62(4), 151-155.

Leeja, L., Thopil, J.E., (2007). Antimicrobial activity of methanol extract of Origanum majorana L. (Sweet marjoram). Journal of Environmental Biology, 28(1), 145-146.

Liu, Q., Meng, X., Li, YA., Zhao, C.N., Tang, G.Y., and Li, H.B., (2017). Antibacterial and Antifungal Activities of Spices.
International Journal of Molecular Sciences, 18(6), 2-62.

Moure, A., Cruz, J. M., Franco, D., Domínguez, J. M., Sineiro, J., Domínguez, H., Nuñez, M. J. and Parajó, J. C., (2001). Natural Antioxidants from Residual Sources. Food Chemistry, 72(2), 145-171.

Mohamed, H.M.H., Mansour, H.A., (2012). Incorporating essential oils of marjoram and rosemary in the formulation of beef patties manufactured with mechanically deboned poultry meatto improve the lipid stability and sensory attributes. Journal of Food Science and Technology, 45(1), 79-87.

Mossa, A.T., Nawwar, G.A, (2011). Free radical scavenging and antiacetylcholinesterase activities of Origanum majorana L. essential oil. Human and Experimental Toxicollogy, 30(10), 1501-1513.

Marquesa, J.D.L., Volcao, L.M., Funck, G.D., Kroning, I.S., Silva, W.P.D., Fiorentini, A.M., Ribeiro, G.A., (2015). Antimicrobial activity of essential oils of Origanum vulgare L. and Origanum majorana L. against Staphylococcus aureus isolated from poultry meat. Industrial Crops and Products, 77, 444-450.

Mith, H., Dure, R., Delcenserie, V., Zhiri, A., Daube, G., Clinquart, A., (2014). Antimicrobial activities of commercial essential oils and their components against food-borne pathogens and food spoilage bacteria. Food Science \& Nutrition, 2(4), 403-416.

Nagy, S., Shaw, P.E., (1985). Tropical and Subtropical Fruits. Composition, Properties and Uses, In: Ihekoronye, A.I., Ngoddy, P.O. (Ed.), Integrated Food Science and Technology for the Tropics. (pp. 293), London, Macmillan Publishers.

Nessrien, M., Yasin, N., Abou-Taleb, M., (2007). Antioxidant and antimicrobial effects of marjoram and thyme in coated refrigerated semi fried mullet fish fillets, World Journal of Dairy \& Food Sciences, 2(1), 01-09.

Oztaskin, N., Cetinkaya, Y., Taslimi, P., Goksu, S., Gulcin, I., (2015). Antioxidant and 
Acetylcholinesterase Inhibition Properties of Novel Bromophenol Derivatives. Bio organic Chemistry, 60, 49-57.

Omara, S.T., Sherein, I., Moez, A.L., Mohamed, A.M., (2014). Antibacterial Effect of Origanum majorana L. (Marjoram) and Rosmarinus officinalis L. (Rosemary) Essential Oils on Food Borne Pathogens Isolated from Raw Minced Meat in Egypt. Global Veterinaria, 13(6), 1056-1064.

Ouedrhiri, W., Balouiri, M., Bouhdid, S., Moja, S., Chahdi, F.O., Taleb, M., Greche, H.,(2016). Mixture design of Origanum compactum, Origanummajorana and Thym us serpyllum essential oils:Optimization of their antibacterial effect. Industrial Crops and Products, 89, 1-9.

Polat, K.L., Gulcin I., Goren, A. C., Namiesnik, J., Martinez-Ayala, A. L., Gorinstein, S., (2015). LC-MS/MS Analysis, Antioxidant and Anticholinergic Properties of Galanga (Alpinia officinarum Hance) Rhizomes. Industrial Crops and Products, 74, 712721.

Prakash, Singh, B., Kedia, P., Dubey, A., N.K., (2012). Assessment of some essential oil sas food preservatives based on antifungal, antiaflatoxin, antioxidant activities and invivo efficacy in foodsystem. Food Research International, 49(1), 201-208.

Rus, C.F., Pop, G., Alexa, E., Șumalan, R.M., Copolovici, DM., (2015). Antifungal activity and chemical composition of Origanum majorana L. essential oil.Research Journal of Agricultural Science, 47(2), 179-185.

Radaelli, M., da Silvaa, B.P., Weidlich, L., Hoehne, L., Flach, A., Mendonc, L.A., da Costa, A., Ethur, E.M., (2016). Antimicrobial activities of six essential oils commonly used as condiments in Brazil against Clostridium perfringens. Brazalian Journal of Microbiolology, 47(2), 424-430.

Stone, W. L., Leclair, I., Ponder, T., Bagss, G., Barret-Reis, B., (2003). Infants Discriminate between Natural and Synthetic Vitamin E. American Journal of Clinical Nutrition, 77(4), 899-906.
Selim, SA., Mohamed, H., Aziz, A., Mashait, M.S., Warrad, M.F., (2013). Antibacterial activities, chemical constitutes and acute toxicity of Egyptian Origanum majorana L., Peganum harmala L. and Salvia officinalis L. essential oils. African Journal of Pharmacy and Pharmacology. 7(13), 725735.

Shenawy, M.A.E., Baghdadi, H.H., Hosseiny, L.S.E., (2015). Antibacterial activity of plants essential oils against some epidemiologically relevant food-borne pathogens. The Open Public Health Journal, 8, 30-34.

Srinivasan, K:,(2014). Antioxidant potential of spices and their active constituents. Critical Reviews in Food Science and Nutrition, 54(3), 352-372.

Stefanakis, M.,Touloupakis, E., Anastasopoulos, E., Ghanotakis, D., Katerinopoulos,H.E., Makridis, P., (2013). Antibacterial activity of essential oils from plants of the genus Origanum. Food Control, 34(2), 539-546.

Sagdic, O., Ozturk, I., Bayram, O., Kesmen, Z., Yilmaz, M.T., (2010). Characterization of butter spoiling yeasts and their inhibition by some spices. Journal of Food Science, 75(9), M597-M603.

Tohma, H., Koksal, E., Kiliç, O., Alan, Y., Y1lmaz, M. A., Gulcin, I., Bursal, E., Alwasel, S. H., 2016. RPHPLC/MS/MSAnalysis of the Phenolic Compounds, Antioxidant and Antimicrobial Activities of Salvia L. Species. Antioxidants (Basal), 5(4), 1-15.

Topal, F.; Topal, M.; Gocer, H.; Kalın, P.; Koçyigit, U. M.; Gulcin, İ.; Alwasel, S. H. (2015)a. Antioxidant Activity of Taxifolin: An Activity-Structure Relationship. Journal of Enzyme Inhibition and Medicinal Chemistry, 31(4), 674-683.

Topal, M.; Gocer, H.; Topal, F.; Kalin, P.; PolatKose, P.; Gulcin, I.; Cakmak, K. C.; Kucuk, M.; Durmaz, L.;Goren, A. C., Alwasel, S.H., (2015)b. Antioxidant, Antiradical and Anticholinergic Properties of Cynarin Purified from the Illyrian Thistle 
(Onopordum Illyricum L.). Journal of Enzyme Inhibition and Medicinal Chemistry, 31(2), 266-275.

Tsai, P.J., Tsai, T.H., Yu, C.H., Ho, S.C., (2007). Evaluation of NO-suppressing activity of several Mediterranean culinary spices. Food and Chemical Toxicology,45,(3), 440-447.

Tserennadmid, R., Tako, T., Galgoczy, L., Papp, T., Vagvolgyi, T., Gero, L., Krisch, J., (2010). Antibacterial effect of essential oils and interaction with food components. Central European Journal of Biology, 5(5), 641-648.

Vagi. E., Rapavi, E., Hadolin, M., VasarhelyinePeredi, K., Balazs, A,.Blazovics, A., Simandi, B., (2005). Phenolic and triterpenoid antioxidants from Origanum majorana L. herb and extracts obtained with different solvents. Journal of Agaricultural and Food Chemistry. 53(1), 17-21

Viuda-Martos, M., El Gendy, A.N., Sendra, E., Fernandez-Lopez, J., Abd El Razik, K.A., Omer, E.A., Perez-Alvarez, J.A. (2010). Chemical composition and antioxidant and anti-Listeria activities of essential oils obtained from some Egyptian plants. Journal of Agaricultural and Food Chemistry, 58(16), 9063-9070.

Witkowska, A.M., Hickey, D.K., Gomez, A.K., Wilkinson, M., (2013). Evaluation of antimicrobial activities of commercial herb and spice extracts against selected foodborne bacteria. Journal of Food Research, 2(4), 37-54.

Yanishlieva, N. V., Marinova, E., Pokorný, J., (2006). Natural antioxidants from herbs and spices. European. Journal of Lipid Science and Technology, 108(9), 776-793.

Yasin, N.M.N., Abou-Taleb, M., (2007). Antioxidant and antimicrobial effects of marjoram and thyme in coated refrigerated semifried mullet fish fillets. World Journal of Dairy and Food Science, 2(1), 1-9.

Yazdanparast, R., Shahriyary, L., (2008). Comparative effects of Artemisia dracunculus, Satureja hortensis and Origanum majorana on inhibition of blood platelet adhesion, aggregation and secretion. Vascular Pharmacology, 48(1), 32-37. 